ERIKSson, G., A. Johnsson and D. LindGren (1973): Flowering in a cone trial of Picea abies Karst. Studia Forestalia Suecica 110, $45 \mathrm{pp}$.

FARMER, R. E. (1981): Variation in seed yield of white oak. For. Sci. 27(2): 377-380.

Funda, T., C. Chen, C. Liewlaksaneeyanawin, A. Kenawy and Y. A. EL-KASSABY (2008): Pedigree and mating system analyses in a western larch (Larix occidentalis Nutt.) experimental population. Ann. For. Sci. 65: 705. DOI:10.1051/forest:2008055

Funda, T., M. Lstiburek, P. Lachout, J. Klapste and Y. A. EL-KASSABY (2009): Optimization of combined genetic gain and diversity for collection and deployment of seed orchard crops-Tree Genetics and Genomes 5: 583-593.

GRIFFIN, A. R. (1982): Clonal variation in radiata pine. I. Some flowering, cone and seed production traits. Australian Forest Research 12: 295-302.

Gilman, E. F. and D. G. Watson (1994): Fact Sheet ST540 , a series of the Environmental Horticulture Department, Florida Cooperative Extension Service, Institute of Food and Agricultural Sciences, University of Florida, October 1994. 4pp.

Healy, W. M., A. M. Lewis and E. F. Boose (1999): Variation of red oak acorn production. For. Ecol. Manage. 116: $1-11$.

KANG K. S. and D. LindGREN (1999): Fertility variation among clones of Korean pine (Pinus koraiensis S. et Z.) and its implications on seed orchard management. For Genet. 6: 191-200.

KANG, K. S., Y. A. El-Kassaby, S. U. HAN and C. S. KIM (2005): Genetic gain and diversity under different thinning scenarios in a breeding seed orchard of Quercus acutissima. For. Ecol. Manage. 212: 405-410.

KJÆR, E. D. and H. WeLlENDORF (1998): Studies on the effect of unequal flowering on the effective population number in Danish seed orchard crops. Forest Tree Improvement 26: 1-9.

Koenig, W. D., R. L. Mumme, W. J. Carmen and M. T. STANBACK (1994): Acorn production by oaks in central coastal California: variation within and among years. Ecology 75(1): 99-109.

KoREA Forest Research Institute (KFRI) (1990): Studies on the development and utilization of Korean oak resources. Ministry of Science and Technology. Seoul. $449 \mathrm{pp}$.

KREBS, C. J. (2008): Ecology; The experimental analysis of distribution and abundance. Fifth edition. Benjamin Cummings. 608pp.

LEE, C. B. (1979): Korean flora. Hyangmoonsa, Seoul. 990pp.

LINDGREN, D. and K. S. KANG (1997): Status number - a useful tool for tree breeding. Research Report of Forest Genetics Research Institute, Korea 33; 154-165.

LindGren, D., L. D. GEA and P. A. JEFFERSON (1996): Loss of genetic diversity monitored by status number. Silvae Genet. 45: 52-59.

MASAKA, K. and H. SATO (2002): Acorn production by Kashiwa oak in a coastal forest under fluctuating weather conditions. Can. J. For. Res. 32: 9-15.

PREscher, F. (2007): Seed orchards - genetic considerations on function, management and seed procurement. $\mathrm{Ph}$. D. thesis. Umeå, Sweden: Swedish University of Agricultural Sciences.

SAS INSTITUTE (1990): SAS programming tips; a guide to efficient SAS processing. SAS Institute. 176pp.

Savolainen, O., K. KarkKainen, A. HaRJu, T. NikKanen and M. RUSANEN (1993): Fertility variation in Pinus sylvestris: a test of sexual allocation theory. Amr. J. Bot. 80: $1016-1020$.

Sork, V. L., J. BRAmble and O. SeXton (1993): Ecology of mast-fruiting in Missouri oaks. Ecology 74: 528-541.

\title{
Karyotypic Studies in Ecotypes of Hippophaë rhamnoides L. from Romania
}

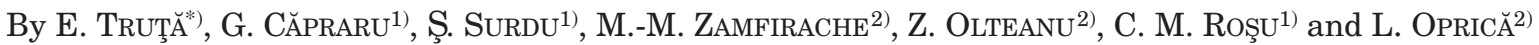

(Received 30 ${ }^{\text {th }}$ December 2009)

\begin{abstract}
Sea buckthorn is a dioecious Eurasian shrub or small tree with large morphological, biochemical and physiological variability, evidenced by the great number of studies. Cytogenetically, uncertainties exist on species basic number, ploidy level, and sex chromosomes. In this study, detailed cytogenetic measurements were carried out on six Romanian ecotypes belonging to Hippophaë

\footnotetext{
1) Biological Research Institute, Iaşi, Romania.

$\left.{ }^{2}\right)$ Faculty of Biology, University "Alexandru Ioan Cuza”, Iaşi, Romania.

*) Corresponding author: Elena TRUŢǍ. Department of Cell Biology, Biological Research Institute, Lascar Catargi street 47, 700107 Iaşi, Romania, Fax: +40-232218121. E-Mail: trutaelena@yahoo.com
}

rhamnoides L. ssp. carpatica Rousi, in order to establish the features and the symmetry degree of karyotypes, to evidence the sex chromosomes, and to construct the idiogram. The ecotypes have $2 \mathrm{n}=24$ metacentric and submetacentric chromosomes. An intraspecific variation exists concerning the proportion of these two morphotypes. The karyotypes have similar symmetry patterns $(\mathrm{R}=2.57-2.89 ; \mathrm{TF} \%=38.54-42.70 ; \mathrm{AsI} \%=57.99-61.41$; $\left.\mathrm{A}_{1}=0.27-0.35 ; \mathrm{A}_{2}=0.26-0.36\right)$ and belong to $1 \mathrm{~B}$ and $2 \mathrm{~B}$ classes, being relatively high symmetric. Based on obtained results, we presume that the male sex chromosomes are heteromorphic, while in female plants are homomorphic. The Y chromosome is larger than X chromosome.

Key words: Hippophaë rhamnoides L. ssp. carpatica Rousi, heterosomes, idiogram, karyotype. 


\section{Introduction}

The genus Hippophaë (Eleagnaceae) is widely but fragmentally distributed in Asia and Europe, between $27^{\circ}-69^{\circ} \mathrm{N}$ latitude and $7^{\circ} \mathrm{W}-122^{\circ} \mathrm{E}$ longitude (Rousi, 1971; LIAN et al., 2000; BARTISH et al., 2002), but during the last decade, the sea buckthorn became an important subject for domestication in Canada and USA (LI and BEvERIDGe, 2003). There is a notable worldwide increasing interest in exploitation of the nutritive, decorative, medicinal, cosmetic, ecological, and agricultural valences of Hippophaë rhamnoides L., the most important species of the genus (ZHAO, 1992; YAO and TigERSTEDT, 1994; SINGH, 2003).

After 1753, when Linnaeus named sea buckthorn as $H$. rhamnoides L., several other species were found and named by many taxonomists. The data are controversial mainly concerning the classification within the genus which was subjected to numerous modifications (TANG, 2002). Especially the Chinese taxonomists modified it few times over the years by adding new taxa, some of these with possible hybrid origins (BARTISH et al., 2002; SwEnson and BARTISH, 2008). Two moments with repercussions on sea buckthorn classification are the reporting of a new species $-H$. neurocarpa S.W. Liu \& T. N. He - (LIU and HE, 1978) and of a new subspecies $H$. rhamnoides ssp. wolongensis Y. S. Lian, K. Sun \& X. L. Chen - (LIAN et al., 2003). Originally, the genus consisted of only one species $-H$. rhamnoides - with 3 subspecies: rhamnoides, salicifolia, and tibetana. RousI, 1971 divided the species $H$. rhamnoides into 9 subspecies - carpatica, caucasica, fluviatilis, gyantsensis, mongolica, rhamnoides, sinensis, turkestanica, and yunnanensis. LIAN et al., 2000 reconsidered the sea buckthorn taxonomy and raised a new taxonomic system of Hippophä, according to which 6 species and 12 subspecies exist in this genus: $H$. rhamnoides L. (ssp. carpatica Rousi; ssp. caucasica Rousi; ssp. fluviatilis van Soest; ssp. mongolica Rousi; ssp. rhamnoides; ssp. sinensis Rousi; ssp. turkestanica Rousi; ssp. yunnanensis Rousi), H. salicifolia D. Don, H. goniocarpa (Lian) X. L. Chen \& K. Sun (ssp. litagensis Lian \& X.L. Chen; ssp. goniocarpa Lian), H. gyantsensis (Rousi) Lian, H. neurocarpa S. W. Liu \& T. N. He (ssp. stellatopilosa Lian \& L. Chen; ssp. neurocarpa S. W. Liu \& T. N. He), H. tibetana Schlecht.

The modern phylogenetic technologies involving molecular markers (BARTISH et al., 2002; SwENSON and BARTISH, 2003) confirmed the hybrid origins of two Chinese taxa - goniocarpa and litangensis - considered two subspecies of the same species. The correlation of the results on chloroplast DNA analysis with the previous data on isoenzymes and RAPD markers allowed to the authors to conclude that the two taxa are indeed two different species, thus the genus Hippophä̈ comprising seven species and eight subspecies. In spite of these results, RUAN refers in 2006 to the existence of 6 species and 12 subspecies.

The modern techniques of molecular biochemistry and genetics were also used to determine the sea buckthorn genetic variability and to elucidate the genus taxonomy: $R A P D$ (Random Amplified Polymorphic DNA) markers
(JEPPSSON et al., 1999; BARTISH et al., 2000; CHOWDHURY et al., 2000; SHENG et al., 2006; Sun et al., 2006), cp DNA (chloroplast DNA) (BARTISH et al., 2002), ITS (internal transcribed spacer) (Sun et al., 2003), AFLP (Amplified Fragment Length Polymorphism) markers (RUAN and LI, 2005; RUAN, 2006), ISSR (inter-simple sequence repeats) markers (TIAN et al., 2004), DNA microsatellite loci (WANG et al., 2008), intron sequences (chalcone synthase intron - Chsi) (BARTISH et al., 2006). However, in spite of these numerous molecular, taxonomic and phylogenetic studies, there are still undeciphered zones concerning the sea buckthorn classification. The relationships between taxa remain in dispute and require further clarifications especially at species and subspecies levels because some specialists think that some of geographically separated subspecies deserve the rank of species (SMALL et al., 2002).

The phenotypic and genotypic studies revealed a very large variability in all sea buckthorn provenances, and the Romanian sea buckthorn resources are not the exception concerning the high morphological, biochemical and cytogenetic diversity in this species (OLTEANU et al., 2009; OPRICA et al., 2009; TRUŢǍ et al., 2009; ZAMFIRACHE et al., 2009). The high level of variability amplitude is the result of long term evolution and it constitutes the evolutive potential of the species, because it assures the basis for selection and amelioration activities.

H. rhamnoides L. is an important plant in Romania, although its valences are not yet entirely exploited. In the last years, the research interest was focused on the realization of an inventory of Romanian sea buckthorn resources by their complex phenotypic and genotypic characterization, construction of a large theoretical and practical basis for the selection of valuable genotypes, and establishment of a germplasm national fund.

The literature is very rich regarding the sea buckthorn chemical composition, but there is a paucity of data on the chromosome constitution of this species. The cytogenetic studies establish the chromosome number of a species and help to decipher the morphological particularities of chromosomes and the metric characteristics of these, followed by karyotype construction. The pattern of chromosome formula, the presence of ploidy level, the existence of some chromosome anomalies can be discussed in relation with respective phenotypes and can direct the activities of selection and amelioration. Hippophaë rhamnoides is a dioecious species with a pronounced sexual dimorphism and the knowledge of cytogenetic indicators is necessary and important.

For these reasons, the main objectives of this study are the following:

- the establishment of chromosome diploid number;

- the analysis of the morphological traits of somatic chromosomes, and the construction of karyotypes of investigated ecotypes in view to evidence the intraspecific variation of karyotypic features;

- the identification of some differences which will per mit us to infirm or confirm the existence of heterosomes in this dioecious species;

- the construction of sea buckthorn idiogram. 


\section{Materials and Methods}

Seeds from individuals of six Hippophaë rhamnoides ssp. carpatica Rousi Romanian ecotypes (noted as HRL2; HR-S16; HR-C1; HR-L4; HR-B8; HR-Bu2) were used as biological material for cytogenetic investigations. The germination was carried out at $22^{\circ} \mathrm{C}$, in dark. At $10-15$ $\mathrm{mm}$ length, the root tips were pretreated with 8-hydroxyquinoline $(0.002 \mathrm{~mol} / \mathrm{L})$, for $4 \mathrm{~h}$ and were fixed in ethanol-acetic acid mixture (3:1) for $24 \mathrm{~h}$ at room temperature. The plant material was stored in refrigerator, at $4{ }^{\circ} \mathrm{C}$, in $70 \%$ alcohol. In view of analysis, the root tips were hydrolyzed in $50 \%$ hydrochloric acid for 8 minutes. A modified carbol fuchsin solution (GAMBORG and WETTER, 1975) was an effective stain for sea buckthorn chromosomes. The squash preparations were obtained in $45 \%$ glacial acetic acid. Microscopic investigation was carried out by a Nikon Eclipse 600 microscope. For morphometric analysis, the cells with well-spread metaphase chromosomes were photographed with digital camera Cool Pix Nikon, 1600 x 1200 dpi, 100x objective. The images were processed by Adobe Photoshop programmer.

Chromosome measurements included length of individual chromosomes (C), long arm length (L), short arm length $(\mathrm{S})$, arm ratio, $\mathrm{r}(\mathrm{r}=\mathrm{L} / \mathrm{S})$, centromeric index, $\mathrm{CI}$ $(\mathrm{CI}=\mathrm{S} / \mathrm{C} \times 100)$, and the relative length of each chromosome, \% (C/length of haploid complement x 100).

Karyotypes were performed according to LEVAN et al., 1964 nomenclature. The chromosome homology and the establishment of the chromosome types were assigned on the basis of centromere position, respectively on CI and $r$ values: the chromosomes are metacentric $(\mathrm{r}<1.70, \mathrm{CI}=37.5-50.0)$, submetacentric $(\mathrm{r}=1.70-2.99$, $\mathrm{CI}=37.5-25.0), \quad$ subtelocentric $\quad(\mathrm{r}=3.00-6.99, \quad \mathrm{CI}=$ 25.0-12.5), and telocentric $(\mathrm{r}=7.00-\infty, \mathrm{CI}<12.5)$. In karyotypes, the chromosome pairs have been ordered in decreasing size. Idiograms were drawn based on the mean values recorded for all karyotypes.

To evaluate the karyotype asymmetry, the following indexes were analyzed: TF\%, AsI\%, R, $\mathrm{A}_{1}$ and $\mathrm{A}_{2}$. STEBBINS' classification (1971) was employed to establish the asymmetry classes.

The total form percent (TF\%) (HUZIWARA, 1962) is expressed by the ratio between sum of the lengths of the short arms of individual chromosomes to the total haploid complement length: $\mathrm{TF} \%=\left(\sum\right.$ short arms $/$ total complement length) $x 100$.

AsI \% index (ARANO and SAITO, 1980) represents the ratio between the sum of the lengths of long arms and total haploid complement length: AsI $\%=\left(\sum\right.$ long arms $/$ haploid complement length) x 100 .

$R$ represents the ratio of the longest to the shortest chromosome pair (BAEZA et al., 2007).

The intrachromosomal asymmetry index $\left(\mathrm{A}_{1}\right)$ and the interchromosomal asymmetry index $\left(\mathrm{A}_{2}\right)$ were calculated according to ROMERO ZARCO, 1986:

$\mathrm{A}_{1}=1-\left[\sum(\mathrm{b} / \mathrm{B}) / \mathrm{n}\right]$, where $b$ and $B$ are the mean length of short and long arms of each pair of homologues, respectively, $n$ is the number of homologues;

$\mathrm{A}_{2}=\mathrm{s} / \mathrm{x}$, where $s$ is the standard deviation, and $x$ the mean chromosome length.

\section{Results and Discussion}

Karyotypic features of the studied Romanian sea buckthorn ecotypes

The karyotypes, which describe the complement phenotypes in terms of number, size, arm ratio, and other chromosome specific features, are dynamic structures evolving through numerical and structural changes (LEVIN, 2002). The above mentioned parameters may differ even between closely related taxa. For Hippophä̈, the karyotypic studies are, with few exceptions, limited to somatic chromosome counts. The seed internal dormancy making heavier the germination, the high chromosome stickiness making more difficult the obtainment of well spread preparations, and the reduced size of chromosomes are the main explanations for the reduced number of cytogenetic approaches. In this research, the detailed analysis of karyotypes evidenced a relatively high degree of intraspecific uniformity for all studied variables in the six studied ecotypes (Table 1, Figure 1). The metaphases of somatic cells displayed 24 chromosomes. $2 \mathrm{n}=24$ is the diploid number repeatedly reported in the literature, the data being quasi-unanimous to sustain the existence of this chromosome number for all studied varieties, independently of their Asian or European provenance (ROUSI, 1971; SHCHAPOV, 1979; Cireasa and Dascalu, 1983-1984; CAO and LU, 1989; CimpeAnU et al., 2004; RUAN and LI, 2005). Its widespread occurrence suggests that it is probably the true diploid number of Hippophaë rhamnoides species (Rousi, 1971). Some different opinions exist relative to the sea buckthorn ploidy level and basic chromosome number - x (COOPER, 1932; DARMER, 1947; KOVACS and RACZ, 1974; LEVEQUE and GoRENFLOT, 1969). In accordance to LIMA-DE-FARIA, 1980, the sea buckthorn chromosomes can be classified as small, they having sizes lower than $4 \mu \mathrm{m}$. Only HR-B8 ecotype has one chromosome pair exceeding $4 \mu \mathrm{m}$, all the other chromosomes having sizes smaller than $3.5 \mu \mathrm{m}$. The mean absolute length of individual chromosomes varies between $4.08 \mu \mathrm{m}$ (HR-B8 ecotype) and $1.05 \mu \mathrm{m}$ (HR-Bu2 and HRL4 ecotypes), with a mean chromosome length/complement ranging from $2.24 \pm 0.23 \mu \mathrm{m}$ to $1.81 \pm 0.16 \mu \mathrm{m}$. Because of the small and very small sizes of chromosomes, it is somewhat difficult to make a very exact determination of centromere position especially for the chromosomes smaller than $2 \mu \mathrm{m}$ where the details are few distinguishable. The length of haploid complement is comprised between $26.98 \mu \mathrm{m}$ and $21.73 \mu \mathrm{m}$. No secondary constrictions and satellites were evidenced.

According to the values of arm ratios and centromeric indexes, all the karyotypes have exclusively metacentric (m) and submetacentric (sm) chromosomes, the metacentrics being more frequent; some differences are present in the proportion of these chromosome morphotypes. Our results on the existence of only $\mathrm{m}$ and sm chromosome types in sea buckthorn are in agreement with the reports of CIREASA and DASCALU, 1983-1984 $(2 \mathrm{n}=8 \mathrm{~m}+16 \mathrm{sm})$; CAO and Lu, 1989; Cimpeanu et al., $2004(2 \mathrm{n}=20 \mathrm{~m}+4 \mathrm{sm})$.

CAO and LU, 1989 established the karyotype formula for five Chinese $H$. rhamnoides subspecies, as following: $H$. rhamnoides L. ssp. gyantsensis 
Table 1. - Karyotype features in the six studied sea buckthorn ecotypes. $2 \mathrm{n}=$ somatic chromosome number, LHC $=$ length of haploid complement, $\mathrm{CL}=$ chromosome length, range $=$ largest chromosome - smallest chromosome, $\mathrm{CI}=$ centromeric index, $\mathrm{R}=$ ratio of the longest to the shortest chromosome pair, $\mathrm{AsI} \%=$ asymmetry index, $\mathrm{TF} \%=$ total form percent, $\mathrm{A}_{1}=$ intrachromosomal asymmetry index, $\mathrm{A}_{2}$ = interchromosomal asymmetry index.

\begin{tabular}{|c|c|c|c|c|c|c|c|c|c|c|c|c|}
\hline Ecotypc & $2 n$ & Karyotype formula & $\mathrm{LHC}(\mu \mathrm{m})$ & $\begin{array}{c}\mathrm{CL}(\mu \mathrm{m}) \\
- \\
x \pm \mathrm{SE}\end{array}$ & Range $(\mu \mathrm{m})$ & $\begin{array}{c}\mathrm{CI} \\
\bar{x} \pm \mathrm{SE}\end{array}$ & $\mathrm{R}$ & AsI $\%$ & $\mathrm{TF} \%$ & $\mathrm{~A}_{1}$ & $\mathrm{~A}_{2}$ & $\begin{array}{c}\text { Stebbins } \\
\text { class }\end{array}$ \\
\hline HR- L2 & 24 & $\begin{aligned} & 2 \mathrm{n}= 23 \mathrm{~m}+1 \mathrm{sm} \text { (putative } \\
&\text { malc: } 22+X Y)\end{aligned}$ & 22.41 & $1.87 \pm 0.15$ & $3.29-1.27$ & $40.17 \pm 0.32$ & 2.59 & 59.97 & 40.07 & 0.33 & 0.29 & $1 \mathrm{~B}$ \\
\hline HR-S16 & 24 & $\begin{aligned} 2 \mathrm{n}= & 18 \mathrm{~m}+6 \mathrm{sm} \text { (putative } \\
& \text { malc: } 22+X Y)\end{aligned}$ & 22.20 & $1.85 \pm 0.16$ & $2.93-1.10$ & $39.67 \pm 2.16$ & 2.66 & 59.59 & 40.00 & 0.34 & 0.30 & $2 \mathrm{~B}$ \\
\hline HR-L4 & 24 & $2 n=22 m+2 s m$ & 21.73 & $1.81 \pm 0.16$ & $2.90-1.05$ & $41.89 \pm 1.17$ & 2.74 & 58.12 & 42.70 & 0.27 & 0.30 & 1B \\
\hline HR-B8 & 24 & $2 n=16 m+8 s m$ & 26.98 & $2.24 \pm 0.23$ & $4.08-1.43$ & $38.80 \pm 2.18$ & 2.84 & 59.63 & 40.43 & 0.35 & 0.36 & $2 \mathrm{~B}$ \\
\hline HR-Bu2 & 24 & $2 n=18 m+6 s m$ & 22.57 & $1.88 \pm 0.17$ & $3.04-1.05$ & $40.33 \pm 2.02$ & 2.89 & 57.99 & 41.95 & 0.31 & 0.31 & $2 \mathrm{~B}$ \\
\hline
\end{tabular}

$2 \mathrm{n}=2 \mathrm{x}=24=18 \mathrm{~m}+6 \mathrm{sm} ; H$. rhamnoides $\mathrm{L}$. ssp. sinensis $2 \mathrm{n}=2 \mathrm{x}=24=18 \mathrm{~m}+6 \mathrm{sm} ; \quad H$. rhamnoides L. $\mathrm{ssp}$. turkestanica $2 \mathrm{n}=2 \mathrm{x}=24=20 \mathrm{~m}+4 \mathrm{sm} ; H$. rhamnoides $\mathrm{L}$. ssp. yunnanensis $2 \mathrm{n}=2 \mathrm{x}=24=14 \mathrm{~m}+10 \mathrm{sm}$; $H$. rham noides L. ssp. mongolica $2 \mathrm{n}=2 \mathrm{x}=24=16 \mathrm{~m}+8 \mathrm{sm}$, but also for other three sea buckthorn species: $H$. neurocarpa $2 \mathrm{n}=2 \mathrm{x}=24=18 \mathrm{~m}+6 \mathrm{sm} ; H$. tibetana $2 \mathrm{n}=2 \mathrm{x}=24=$ $14 \mathrm{~m}(2 \mathrm{sat})+8 \mathrm{sm} ;$ H. salicifolia $2 \mathrm{n}=2 \mathrm{x}=24=10 \mathrm{~m}+14 \mathrm{sm}$.

The mean values of asymmetry indexes of karyotypes are close: $\mathrm{R}$ ranges from 2.57 to 2.89 , AsI\% has values comprised between 57.99 and 61.41 , and $\mathrm{TF} \%$ varies from 38.54 to 42.70 . The detailed and comparative analysis shows that HR-C1 ecotype has the most asymmetric karyotype having a smaller TF\% (38.54\%) and a greater $\mathrm{A}_{1}$ index (0.39) than the other five karyotypes (Table 1).

Also, this karyotype has the most increase value of AsI\% (61.41\%) and the lowest value of interchromosomal index $\mathrm{A}_{2}$ (0.26). It has approximately $55 \%$ metacentric chromosomes with median placed centromere. The most symmetric karyotype is HR-L4, with the highest value of $\mathrm{TF} \%(42.70 \%)$ and the lowest $\mathrm{A}_{1}$ index (0.27). According to STEBbins' classification (1971), the karyotypes HR-L2 and HR-L4 are of 1B category - they have all the chromosomes with $r<2: 1$, while $\mathrm{R}$ is 2.59 , respectively 2.76. Also, these karyotypes have more than $90 \%$ metacentric chromosomes with median centromere. The other four karyotypes belong to $2 \mathrm{~B}$ class, with $75-83 \%$ metacentric chromosomes having $\mathrm{r}<2: 1$ and $\mathrm{R}$ varying between 2.57-2.89. The $1 \mathrm{~B}$ and $2 \mathrm{~B}$ classes of the Stebbins' classification are considered relatively primitive; 2B karyotypes are considered more evolved than those included in 1B class.

The karyotypes having chromosomes smaller than 4 $\mu \mathrm{m}$ and predominantly of $\mathrm{m}$ and sm type are considered as being primitive, little evolved, because they have not been supported significant restructurations and rearrangements during evolution (STEBBINs, 1971; ACOSTA et al., 2005; PASZKo, 2006). STEBBINS, 1971 stated that the tendency to karyotype asymmetrization by the increase of the number of telocentric chromosomes in spite of those of metacentric and submetacentric type represents a progressive step in karyotype evolution and has repercussions on species evolution. According to pre- vious considerations and on the basis of our results, the ecotypes of Hippophaë rhamnoides ssp. carpatica Rousi have rather symmetric karyotypes, being relatively little evolved. By comparing them, the most asymmetric and, thus, the most evolved is HR-C1 ecotype, while HRL2 and HR-L4 ecotypes have the most symmetric, therefore more primitive karyotypes.

\section{Sex chromosomes in sea buckthorn}

Another interesting problem is that of sea buckthorn sex determination. In dioecious species, the sex is genetically determined, either by morphologically differentiated sex-chromosomes, either by allele expression at one or several autosomal loci, placed on morphologically non-distinguishable chromosomes. For commercial production of sea buckthorn berries, only $7-12 \%$ of male individuals (sex ratio of $10: 6 q-10: 8 \%$ ) are necessary as producers of fertile pollen and pollinators (JANA et al., 2002; LI, 2002). The breeding efforts are mainly orientated towards the development of valuable female phenotypes and to removal of undesired males by early sex discrimination of plants. Unfortunately, the plant sex can not be established before flowering.

If for certain dioecious plant species the sex determining chromosomal system is well known, for sea buckthorn the thoroughgoing studies are fewer and without details regarding sex chromosomes. Generally, in dioecious plants with dimorphic sex chromosomes, the male is heterogametic (XY) and female is homogametic (XX), like in mammals (AINsworTH, 2000; CHARLESWORTH, 2002). In contrast to the typically small mammalian $Y$ chromosome, in angiosperms the heteromorphic $\mathrm{Y}$ chromosome is often the largest chromosome in the male genome (Silene latifolia - CIUPERCESCU et al., 1990; NAKAO et al., 2002, Cannabis sativa - SAKAмоTо et al., 1998, Rumex acetosa - SHIBATA et al., 1999, Coccinia indica PARKER, 1990). For example, in hemp, a dioecious plant with strong sexual dimorphism, it is accepted the existence of heteromorphic sex chromosomes in male plants: $Y$ chromosome is telocentric, $\mathrm{X}$ chromosome is metacentric. The size genome - $1636 \mathrm{Mbp}$ for female, $1683 \mathrm{Mbp}$ for male - additionally confirms the larger dimensions of $\mathrm{Y}$ chromosome in hemp (SАKАмото et al., 1998). 
In $H$. rhamnoides L., according to several data, the male could be heterogametic and the female homogametic, but the existence of sex chromosomes never was proved in an unquestionable manner. As we previously presented, the somatic chromosome number of $H$. rhamnoides $\mathrm{L}$. is $2 \mathrm{n}=24$, but there is little information concerning karyotype, genome or DNA, and sex chromosomes. SHCHAPOV, 1979 reported the presence of male heteromorphic chromosomes and the existence of an $\mathrm{X} / \mathrm{Y}$ system determining sea buckthorn sexual phenotype. CAO and LU, 1989 published data on chromosome size and morphology in Chinese varieties, but they not identified heteromorphic sex chromosomes. In the studied ecotypes, we find two categories of karyotypes: one with twelve homologous chromosome pairs and another with eleven homologous chromosome pairs and one pair with heteromorphic chromosomes. These data permit us to presume, on the basis of their size and morphology, the existence of sex chromosomes in sea buckthorn (Figures 1 and 2) - see section Idiogram in $H$. rhamnoides L. for details.

Obviously, the mechanism governing gender determination in sea buckthorn still needs further research, especially at molecular level, in view to solve all uncer- tainties concerning this important problem of large practical interest. Till now, utilization of molecular markers - especially RAPD - closely linked to sex determination is irrelevant. For example, in the research of Persson and NyBOM, 1998, although in the F1 descendance of one cross, the RAPD marker was present both in male parental and in all male descendants and was absent in all female individuals, it can not be considered universal, because in F1 progenies of another cross it was present in only one of the males. If sex chromosomes exist in Hippophä, it is plausible that they are very similar in DNA composition, since it was not discovered a general sex specific marker although 80 primers were tested (PERSSON and NyBOM, 1998). Anyhow, in dioecious plants without identified sex chromosomes, the markers for maleness indicate either the presence of cytologically not evidenced sex chromosomes either that the respective markers are tightly linked to genes involved in sex determination (AINSWORTH, 2000).

\section{Sea buckthorn idiogram}

Idiograms were constructed for both female (Figure $2 A$ ) and male individuals (Figure $2 B$ ) on the basis of the mean values calculated for the six ecotypes of sea buck-

A.
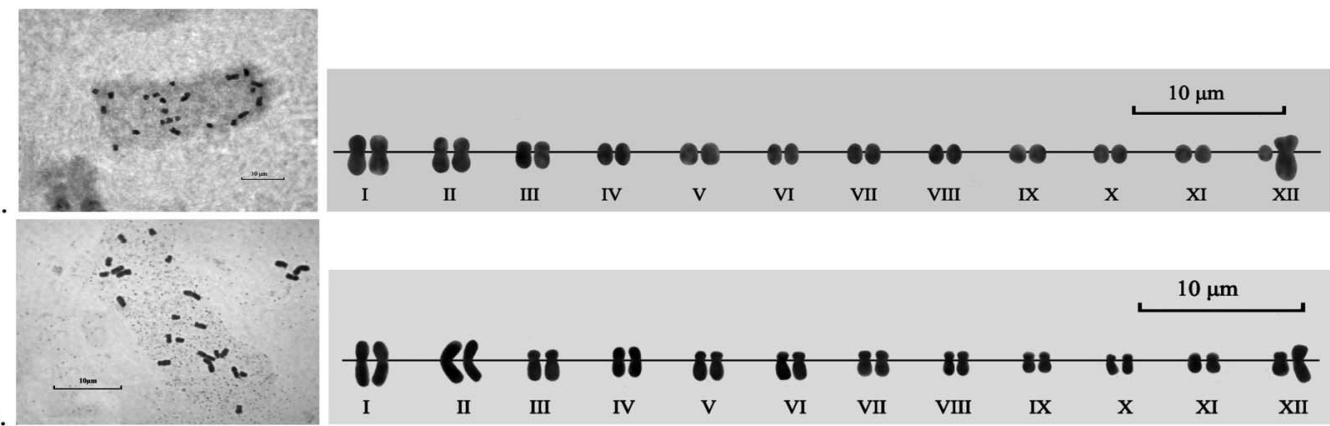

B.
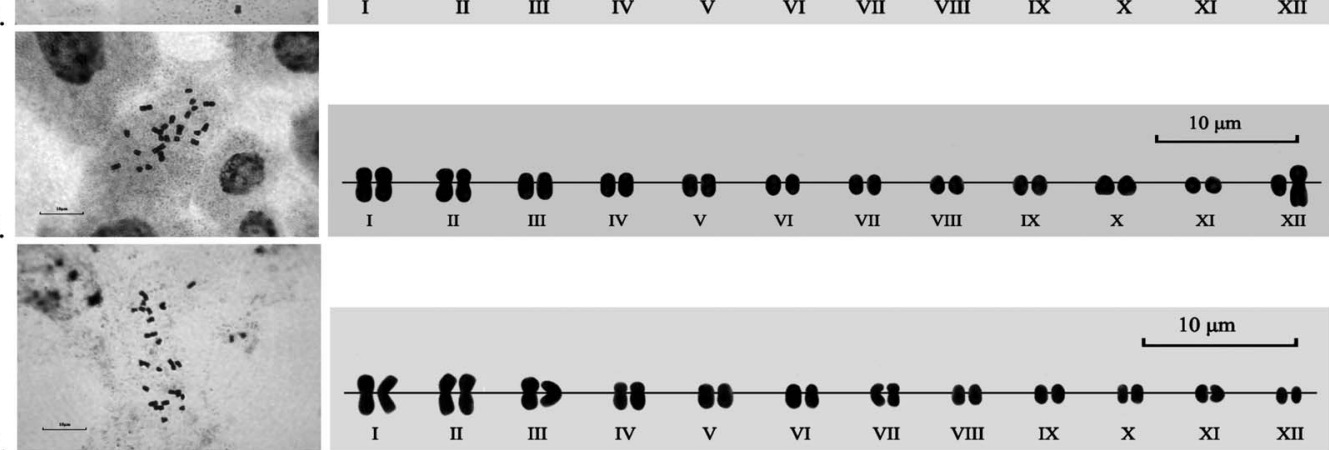

D.
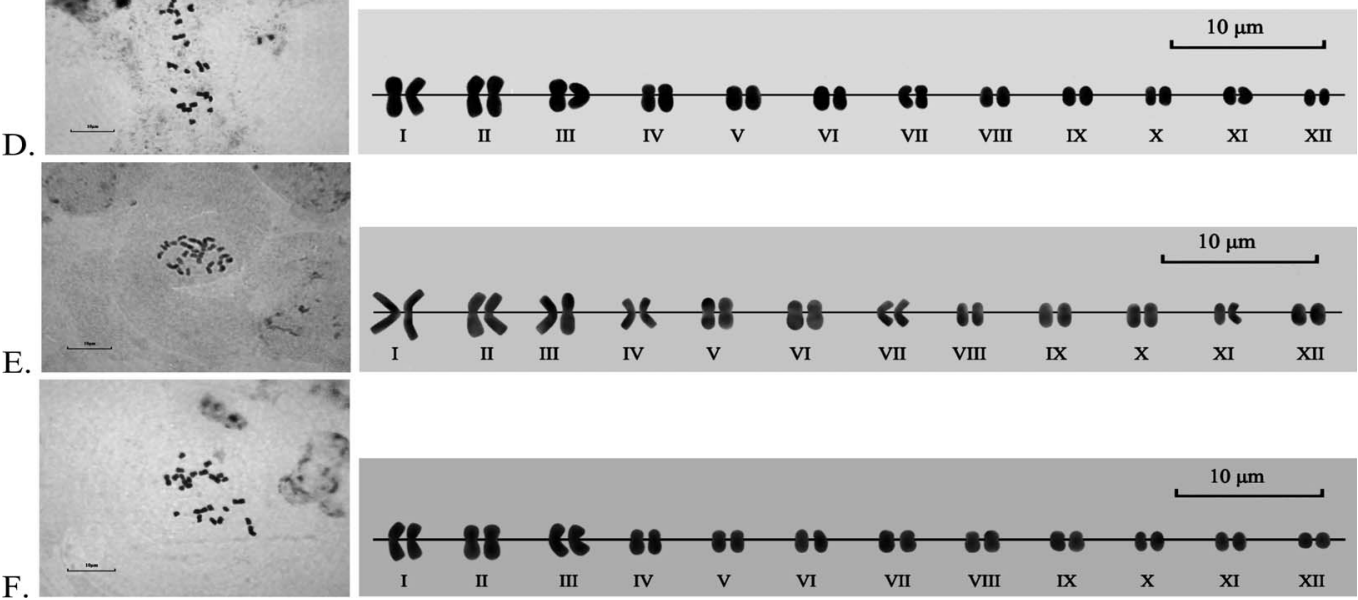

Figure 1. - Metaphases and karyotypes in sea buckthorn Romanian ecotypes: A. HR-L2 ecotype (male); B. HR-S16 ecotype (male); C. HR-C1 ecotype (male); D. HR-L4 ecotype (female); E. HR-B8 ecotype (female); F. HR-Bu2 ecotype (female). 

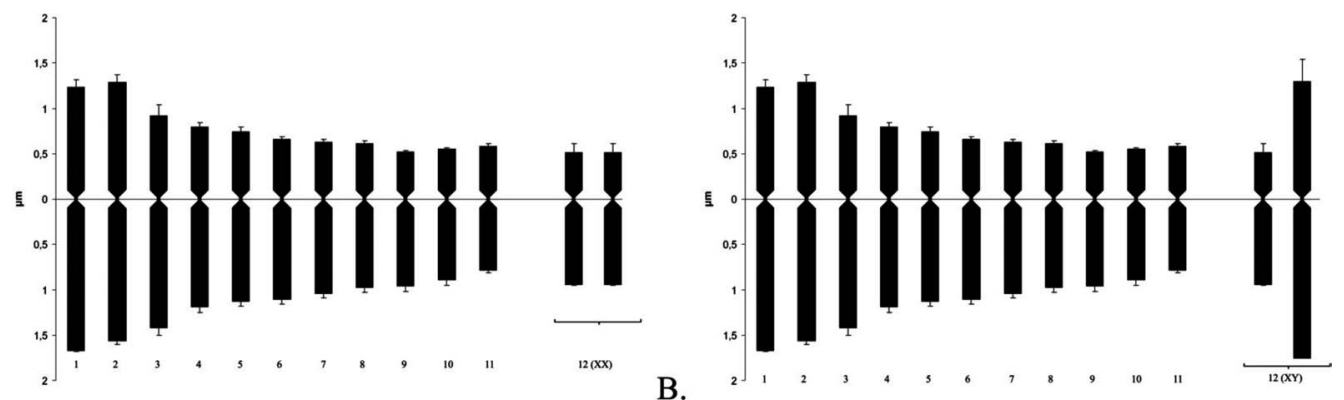

A.

B.

Figure 2. - Sea buckthorn idiograms: female (A) and male (B). Both idiograms are at the same scale.

Table 2. - Average values of cytogenetic parameters of the six studied sea buckthorn ecotypes, calculated for idiogram construction.

\begin{tabular}{|c|c|c|c|c|c|c|c|c|c|c|}
\hline \multirow{2}{*}{\multicolumn{2}{|c|}{$\begin{array}{c}\text { chromosome } \\
\text { pair }\end{array}$}} & \multicolumn{2}{|c|}{ chromosome length $(\mu \mathrm{m})$} & \multicolumn{2}{|c|}{ long arm length $(\mu \mathrm{m})$} & \multicolumn{2}{|c|}{ short arm length $(\mu \mathrm{m})$} & \multirow{2}{*}{$\begin{array}{l}\bar{x}_{ \pm \mathrm{SE}} \\
\bar{x}_{\mathrm{S}}\end{array}$} & \multirow{2}{*}{$\begin{array}{c}\text { centromeric index } \\
- \\
x \pm \mathrm{SE}\end{array}$} & \multirow{2}{*}{$\begin{array}{c}\text { relative length }(\%) \\
- \\
x \pm \mathrm{SE}\end{array}$} \\
\hline & & $x \pm \mathrm{SE}$ & range & $x \pm \mathrm{SE}$ & range & $x \pm \mathrm{SE}$ & range & & & \\
\hline \multicolumn{2}{|l|}{ I } & $3.11 \pm 0.19$ & $4.08-2.78$ & $1.67 \pm 0.1$ & $2.17-1.45$ & $1.23 \pm 0.09$ & $1.91-1.25$ & $1.17 \pm 0.05$ & $46.20 \pm 1.13$ & $13.31 \pm 0.44$ \\
\hline \multicolumn{2}{|l|}{ II } & $2.86 \pm 0.1$ & $3.50-2.64$ & $1.56 \pm 0.04$ & $1.77-1.44$ & $1.29 \pm 0.08$ & $1.73-1.08$ & $1.23 \pm 0.07$ & $45.07 \pm 1.43$ & $12.28 \pm 0.27$ \\
\hline \multicolumn{2}{|l|}{ III } & $2.35 \pm 0.17$ & $3.13-1.95$ & $1.42 \pm 0.08$ & $1.83-1.05$ & $0.92 \pm 0.12$ & $1.33-0.55$ & $1.67 \pm 0.23$ & $38.69 \pm 3.17$ & $10.05 \pm 0.52$ \\
\hline \multicolumn{2}{|l|}{ IV } & $1.99 \pm 0.07$ & $2.39-1.69$ & $1.19 \pm 0.06$ & $1.51-0.99$ & $0.80+0.04$ & $0.94-0.67$ & $1.50+0.09$ & $40.23+1.69$ & $8.58 \pm 0.24$ \\
\hline \multicolumn{2}{|l|}{$\mathrm{V}$} & $1.88 \pm 0.07$ & $2.26-1.68$ & $1.13 \pm 0.05$ & $1.33-0.99$ & $0.74 \pm 0.06$ & $1.09-0.58$ & $1.59 \pm 0.16$ & $39.30 \pm 2.45$ & $8.05 \pm 0.14$ \\
\hline \multicolumn{2}{|l|}{ VI } & $1.76 \pm 0.05$ & $1.99-1.60$ & $1.10 \pm 0.06$ & $1.33-0.94$ & $0.66 \pm 0.03$ & $0.74-0.53$ & $1.70 \pm 0.17$ & $37.62 \pm 1.99$ & $7.56 \pm 0.17$ \\
\hline \multicolumn{2}{|l|}{ VIl } & $1.68 \pm 0.05$ & $1.94-1.56$ & $1.04 \pm 0.05$ & $1.29-0.90$ & $0.63 \pm 0.03$ & $0.94-0.44$ & $1.71 \pm 0.16$ & $37.65 \pm 2.18$ & $7.21 \pm 0.1$ \\
\hline \multicolumn{2}{|c|}{ VIII } & $1.58 \pm 0.03$ & $1.74-1.49$ & $0.97 \pm 0.06$ & $1.24-0.83$ & $0.61 \pm 0.03$ & $0.72-0.43$ & $1.63 \pm 0.21$ & $38.90 \pm 2.71$ & $6.80 \pm 0.08$ \\
\hline \multicolumn{2}{|l|}{ IX } & $1.48 \pm 0.05$ & $1.65-1.27$ & $0.96 \pm 0.06$ & $1.25-0.83$ & $0.52 \pm 0.02$ & $0.61-0.43$ & $1.86 \pm 0.19$ & $35.47 \pm 1.91$ & $6.35 \pm 0.14$ \\
\hline \multicolumn{2}{|l|}{$\mathrm{X}$} & $1.45 \pm 0.06$ & $1.70-1.22$ & $0.89 \pm 0.06$ & $1.05-0.66$ & $0.55 \pm 0.02$ & $0.65-0.48$ & $1.63 \pm 0.13$ & $38.47 \pm 1.91$ & $6.22 \pm 0.15$ \\
\hline \multicolumn{2}{|l|}{$\mathrm{XI}$} & $1.36 \pm 0.06$ & $1.63-1.10$ & $0.78 \pm 0.03$ & $0.88-0.66$ & $0.58 \pm 0.03$ & $0.74-0.44$ & $1.35 \pm 0.06$ & $42.58 \pm 1.16$ & $5.83 \pm 0.17$ \\
\hline \multirow[t]{2}{*}{ XII } & $X$ & $1.45 \pm 0.21$ & $2.29-1.05$ & $0.94 \pm 0.11$ & $1.56-0.70$ & $0.51 \pm 0.10$ & $0.56-0.31$ & $1.85 \pm 0.19$ & $35.73=2.2$ & $6.23 \pm 0.99$ \\
\hline & $\mathrm{Y}$ & $3.02 \pm 0.32$ & $3.40-2.38$ & $1.74 \pm 0.24$ & $1.84-1.27$ & $1.28 \pm 0.14$ & $1.56-1.10$ & $1.37 \pm 0.2$ & $42.64 \pm 3.4$ & $13.2 \pm 1.24$ \\
\hline
\end{tabular}

thorn (Table 2). The mean chromosome length calculated for the species as a whole is $1.94 \mu \mathrm{m}$, this parameter having a range of variability from $3.11 \pm 0.19 \mu \mathrm{m}$ to $1.36 \pm 0.06 \mu \mathrm{m}$. The eleven pairs of autosomes are represented by 8 pairs of m-type chromosomes and 3 pairs of sm-type chromosomes.

Concerning the sex chromosomes, the mean values of total chromosome lengths calculated for idiogram construction establish that the putative $\mathrm{Y}$ chromosome is longer that $\mathrm{X}$ chromosome (3.02 $\pm 0.32 \mu \mathrm{m}$, comparatively to $1.45 \pm 0.10$ ). On the basis of mean $r$ and mean CI, the two putative sex chromosomes are classified as following: $\mathrm{X}$ chromosome is submetacentric, with submedian placed centromere $(\mathrm{r}=1.85 \pm 0.19 ; \mathrm{CI}=35.73 \pm 2.2)$, $\mathrm{Y}$ chromosome is metacentric, with median placed centromere $(r=1.37 \pm 0.20 ; \mathrm{CI}=42.64 \pm 3.4)$.

Therefore, a diploid chromosome formula of $2 \mathrm{n}=22+\mathrm{XX}(16 \mathrm{~m}+8 \mathrm{sm})$, with two putative homomorphic sex chromosomes, was described for female individuals, and $2 \mathrm{n}=22+\mathrm{XY}(17 \mathrm{~m}+7 \mathrm{sm})$, with two putative heteromorphic sex chromosomes, was established for male plants in $H$. rhamnoides ssp. carpatica Rousi.

\section{Conclusions}

Relying on the available data, we conclude that the six Romanian sea buckthorn ecotypes are similar concern- ing the chromosome diploid number $(2 \mathrm{n}=24)$, the presence of two chromosome morphotypes, and the reduced size of these, but also exists an intraspecific karyotype variation, especially at the level of proportion of metacentric and submetacentric chromosomes. The karyotypes are rather symmetric (1B and $2 \mathrm{~B}$ types) and relatively little evolved. In our studies, we find karyotypes with twelve homologous pairs of chromosomes, and karyotypes with eleven homologous chromosome pairs and one pair of heteromorphic chromosomes. On the basis of their size and morphology, we presume the existence of sex chromosomes in sea buckthorn, homomorphic in female, and heteromorphic in male. No satellites were evidenced.

\section{Acknowledgements}

This research was realized in project CEEXBIOTECH 109 from National Research Program of Romania, with the financial support of Ministry of Education and Research.

\section{References}

Acosta, M. G., G. Bernardello, M. Guerra and E. A. Moscone (2005): Karyotype analysis in several South American species of Solanum and Lycianthes rantonnei (Solanaceae). Taxon. 54: 713-723. 
Ainsworth, CH. (2000): Boys and girls come out to play: The molecular biology of dioecious plants. Ann. Bot. 86 211-221.

Arano, H. and H. SAito (1980): Cytological studies in family Umbelliferae 5 . Karyotypes of seven species in subtribe Seselinae. La Kromosomo 2: 471-480.

Baeza, C., O. Schrader, E. Ruiz and M. NegritTo (2007): Análisis comparativo del cariotipo en poblaciones de Alstroemeria aurea R. Graham (Alstroemeriaceae) de Chile. Gayana Bot. 64: 33-39.

BARTiSH, I. V., N. JEPPSON and G. I. BARTISH (2000): Interand intraspecific genetic variation in Hippophaë (Elaeagnaceae) investigated by RAPD markers. Plant Syst. Evol. 225: 85-101.

Bartish, I. V., N. Jeppson, H. Nybom and U. Swenson (2002): Phylogeny of Hippophaë (Elaeagnaceae) inferred from parsimony analysis of chloroplast DNA and morphology. Syst Bot 27: 41-54.

Bartish, I. V., J. K. Kadereit and H. P. Comes (2006): Late Quaternary history of Hippophaë rhamnoides L. (Elaeagnaceae) inferred from chalcone synthase intron (Chsi) sequences and chloroplast DNA variation. Molecular Ecology 15: 4065-4083.

CAO, Y. L. and R. S. LU (1989). Karyotype analysis of Hippophaë L. in China. Acta Phytotaxon. Sin. 27: 118-123.

Charlesworth, D. (2002): Plant sex determination and sex chromosomes. Heredity 88: 94-101.

Chowdhury, M. A., S. JANA and W. R. Schroeder (2000): Phenotypic diversity in four woody species on the Canadian prairies. Can J Plant Sci 80: 137-142.

Cimpeanu, M. M, G. CAPARU, C. S. Cimpeanu and D. Julan (2004): Mitotic chromosomes studies in medicinal plants. 1. Hippophaë rhamnoides L. $(2 \mathrm{n}=24)$. An. St. Univ. "Al I Cuza” Iasi, Gen. Biol. Mol. 5: 166-168.

Cireasa, V. and M. Dascalu (1983-1984): Cariotipul la Hippophaë rhamnoides L. ssp. carpatica (Rousi), Inst. Agronomic "Ion Ionescu de la Brad", Iasi, Lucr. St. Ser. Hort. 27-28: 95-96.

Ciupercescu, D., J. Veuskens, A. Mouras, D. Yi, M. BriQUET and I. NEGRUTIU (1990): Karyotyping Melandrium album, a dioecious plant with heteromorphic sex chromosomes. Genome 33: 556-562.

Cooper, D. C. (1932): The chromosomes of Shepherdia canadensis. Am. J. Bot. 19: 429-431.

DARMER, G. (1947): Rassenbildung bei Hippophaë rhamnoides (Sanddorn). Biol. Zbl. 66: 166-170.

GAmborG, O. L. and L. R. WetTer (eds), 1975: Plant Tissue Culture Methods, National Research Council of Canada, Prairie Regional Laboratory (Saskatoon, Sask): 60-62.

HuZIWARA, Y. (1962): Karyotype analysis in some genera of Compositae. VIII. Further studies on the chromosome of Aster. Amer. J. Bot. 49: 116-119.

JANA, S, W. R. Schroeder and B. BARL (2002): Sea buckthorn cultivar and orchard development in Saskatchewan, ADF Project No. 98000273, Final Report: 1-67 (http://www.agr.gov.sk.ca/apps/).

JePpson, N, I. V. BARTISH and H. A. PERSSON (1999): DNA analysis as a tool in sea buckthorn breeding. In: JANICK, J. (Ed.) Perspectives on new crops and new uses. Alexandria, VA, ASHS Press. pp 338-341.

KovACS, A. I. and E. I. RACZ (1974): Date cromosomologice asupra plantelor medicinale si aromatice, Extras - Note botanice 10: 30 .

Levan, A., A. Fredga and A. A. Sanderberg (1964): Nomenclature for centromeric position in chromosome. Hereditas 52: 201-220.
Leveque, M. and Gorenflot, R. (1969): Prospections caryologiques dans la flore littorale du Boulonnais. Bull. Soc. Bot. Nord. Fr. 22: 27-58.

LEVIN, D. A. (2002): The role of chromosomal change in plant evolution. Oxford Univ. Press, New York, USA, 230 pp.

LI, T. S. C. (2002): Product development of sea buckthorn. In: JANick, J. and Whipkey, A. (Eds.) Trends in new crops and new uses. Alexandria, VA, ASHS Press: pp 393-398.

LI, T. S. C. and T. H. J. BeverIDGE (2003): Sea buckthorn (Hippophaë rhamnoides L.): production and utilization. NRC Research Press, Ottawa, Ontario, 133 pp

Lian, Y. S., S. G. Lu, S. K. Xue and X. L. Chen (2000): Biology and chemistry of the genus Hippophaë. Lanzhou, Gansu Science Technology Press: $226 \mathrm{pp}$

Lian, Y. S., X. L. Chen, K. Sun and R. Ma (2003): A new subspecies of Hippophaё (Elaeagnaceae) from China. Novon. 13: 200-202.

LMA-DE-FARIA, A. (1980): Classification of genes, rearrangements and chromosomes according to the chromosome field. Hereditas 93: 1-46.

LIU, S. W. and T. N. HE (1978): Genus Hippophaë L. from Quing-Zang plateau, Acta Phytotaxon. Sin. 16: 106-108.

NakaO, S., S. Matsunaga, A. Sakai, T. Kuroiwa and S. KAWANO (2002): RAPD isolation of a Y chromosome specific ORF in a dioecious plant, Silene latifolia. Genome 45: 413-420.

Olteanu, Z., M. M. Zamfirache, S. Surdu, L. Oprica, E. Truţă, I. V. Rati, C. Manzu, M. Gurau and C. Rosu (2009): Total lipids and carotenoids content in different biotypes of Hippophaë rhamnoides L. harvested in Romania. In: Proceedings of the $3^{\text {rd }}$ International Sea buckthorn Association Conference, August 12-16, 2007. Université Laval, Québec, Canada: 153-158.

Oprica, L., Z. Olteanu, M. M. Zamfirache, E. Truţă, S. Surdu, I. V. Rati, C. Manzu, M. Gurau and C. Rosu (2009): The content of soluble proteins in Hippophaë rhamnoides ssp. carpatica varieties harvested from different regions of Romania. In: Proceedings of the $3^{\text {rd }}$ International Sea buckthorn Association Conference, August 12-16, 2007. Université Laval, Québec, Canada: $73-79$.

PAszKo, B. (2006): A critical review and a new proposal of karyotype asymmetry indexes. Plant Syst. Evol. 258: $39-48$.

PARKER, J. S. (1990): Sex chromosomes and sexual differentiation in flowering plants. Chromosomes Today 10: 187-198.

Persson, H. A. and H. NyBom (1998): Genetic sex determination and RAPD marker segregation in the dioecious species sea buckthorn (Hippophaë rhamnoides L.). Hereditas 129: 45-51.

Romero ZARCO, C. (1986): A new method for estimating karyotype asymmetry. Taxon. 35: 526-530.

Rousi, A. (1971): The genus Hippophaë L. A taxonomic study. Ann. Bot. Fennici 8: 177-227.

RUAN, C. and D. LI (2005): AFLP fingerprinting analysis of some cultivated varieties of sea buckthorn (Hippophaë rhamnoides). J. Genet. 84: 311-316.

RUAN, C. (2006): Genetic relationships among sea buckthorn varieties from China, Russia and Mongolia using AFLP markers. J. Hortic. Sci. Biotech. 81: 409-414.

SAKAmoto, K., Y. AkiYama, K. FuKuI, H. Kamada and S. SATOH (1998): Characterization, genome size and morphology of sex chromosomes in hemp (Cannabis sativa L.). Cytologia 63: 459-464. 
SHCHAPOV, N. S. (1979): On the karyology of Hippophaë rhamnoides L. Tsitol. Genet. 13: 45-47.

Sheng, H. M., L. Z. An, T. Chen, S. J. Xu, G. X. LiU, X. L. ZHENG, L. L. PU, Y. J. LIU and Y. S. LIAN (2006): Analysis of the genetic diversity and relationships among and within species of Hippophaë (Elaeagnaceae) based on RAPD markers. Plant Syst. Evol. 260: 25-37.

Shibata, F., M. Hizume and Y. KuRoKi (1999): Chromosome painting of Y chromosomes and isolation of a Y chromosome-specific repetitive sequence in dioecious plant Rumex acetosa. Chromosoma 108: 266-270.

SINGH, V. (2003): Geographical adaptation and distribution of sea buckthorn. In: SiNGH, V. (Ed.) Sea buckthorn (Hippophaё L.). A multipurpose wonder plant. New Delhi, India, Indus Publ. Comp.: pp 21-34.

Small, E., P. M. Catling and T. S. C. Li (2002): Blossoming treasures of biodiversity: 5. Sea Buckthorn (Hippophaë rhamnoides L.) an ancient crop with modern virtues. Biodiversity 3: 25-27.

StebBins, L. G. (1971): Chromosomal evolution in higher plants. Cap. IV. Chromosomal changes, genetic recombination and speciation, Edward Arnold Ltd, London: pp 101-105.

Sun, K., R. J. MA and X. L. Chen (2003): Hybrid origin of the diploid species Hippophae goniocarpa evidenced by the internal transcribed spacers (ITS) of nuclear rDNA. Belg. J. Bot. 136: 91-96.

Sun, K., W. Chen, R. MA, X. Chen, A. Li and S. Ge (2006): Genetic variation in Hippophaë rhamnoides ssp. sinensis (Elaeagnaceae) revealed by RAPD markers. Biochem. Genet. 44: 186-197.
Swenson, U. and I. V. BARTiSH (2008): Taxonomic synopsis of Hippophaё (Elaeagnaceae). Nord. J. Bot. 22: 369-374.

TANG, X. (2002): Breeding in sea buckthorn (Hippophaë rhamnoides). Genetics of berry yield, quality and plant cold hardiness. Acad. Dissertation, Univ. of Helsinki, Section of Plant Breeding 11: pp 1-48.

Tian, C., P. NAN, S. ShI, J. Chen and Y. Zhong (2004): Molecular genetic variation in Chinese populations of three subspecies of Hippophaë rhamnoides. Biochem. Genet. 42: 259-267.

Truţă, E., S. Surdu, G. Capraru, I. V. Rati, Z. Olteanu, M. M. ZAMFIRACHE and L. OPRICA (2009): Characteristics of mitotic chromosomes in some Romanian sea buckthorn varieties. In: Proceedings of the $3^{\text {rd }}$ International Sea buckthorn Association Conference, August 12-16, 2007. Université Laval, Québec, Canada: 57-65.

Zamfirache, M. M., Z. Olteanu, E. Truţă, S. Surdu and L. ZAMFIRACHE, (2009): Foliar assimilating pigments in different Hippophaë rhamnoides L. varieties in the Romanian flora. In: Proceedings of the $3^{\text {rd }}$ International Sea buckthorn Association Conference, August 12-16, 2007. Université Laval, Québec, Canada: 67-72.

WANG, A, Q. ZHANG, D. WAN, Y. YANG and J. LIU (2008): Nine microsatellite DNA primers for Hippophaë rhamnoides ssp. sinensis (Elaeagnaceae). Conserv. Genet. 9: 969-971.

ZнАо, H. (1992): Seed collection and field evaluation of Hippophaë rhamnoides, Forest Genetic Resources Information (FAO) 20: 12-17 (http://www.fao.org/ docrep/006/).

\title{
Genetic Correlations Among Field Trials of Norway Spruce Clones Representing Different Propagation Cycles
}

\author{
By K.-A. HöGBerG ${ }^{1)}$ and G. W. DutKowski ${ }^{2)}$
}

(Received $14^{\text {th }}$ January 2010)

\begin{abstract}
Serial cutting propagation means that clones are produced in consecutive propagation cycles, where a new round of cuttings are taken from the previously rooted cuttings, etc. The objective of this study was to judge the importance of propagation cycle on height growth in field trials. In a field trial series with Norway spruce clones, comprising nine trials in four cutting propagation cycles, propagation cycle only had a minor effect on height growth compared to the site effect. For inter-site

\footnotetext{
1) Corresponding author: KARL-ANDERS HöGBERG, The Forestry Research Institute of Sweden, Ekebo 2250, SE-268 90 Svalöv, Sweden. Telephone: +46418471306. Fax: +46418471329 E-mail: karl-anders.hogberg@ @skogforsk.se Tasmania, Locked Bag 55, Hobart 7001, Australia. http://www. plantplan.com
}

2) PlantPlan Genetics, c/o School of Plant Science, University of
\end{abstract}

correlation models where all trials were included, the best fit was obtained by an unstructured model, while the most parsimonious model included constraints on the correlations depending on cycle structure. Model constraints based on grouping of the trials by site productivity did not improve the fit. Testing for generally good performers over a range of different site conditions appears to be a good approach, unless drivers of genotype by environment interaction can be identified.

Key words: cuttings, field performance, genotype $\mathrm{x}$ environment interaction, Norway spruce, propagation effects.

\section{Introduction}

An important purpose of vegetative propagation is to identify and clonally propagate superior genotypes in order to increase the genetic gain compared to a sexual- 